\title{
REFERENCES
}

Brady, S., Procter, R. C. \& Ashworth, U. S. (1934). Bull. Mo. agric. Exp. Sta. no. 220.

Burgess, H. M. (1956). Dog World, 17 August, p. I341.

De Graaf, R. (1664.) Disputatio medica de natura et resu succi pancreatii. Leyden.

Edwards, F. B. (1955). Vet. Rec. 67, 105.

Fouts, P. J. (I943). F. Nutr. 25, 217.

Frost, D. V. \& Dann, F. P. (1944). F. Nutr. 27, 355 .

Greig, J. R. (1953). Brit. vet. F. ro9, I4.

Greig, J. R. (1956). The Sheep Dog. Management and Feeding. London: H.M. Stationery Office.

Madden, S. C., Carter, J. R., Kattus, A. A. Jr., Miller, L. L. \& Whipple, J. H. (1943). F. exp. Med. $77,277$.

McCay, C. M. (1949). Nutrition of the Dog. New York: Comstock Publishing Corp.

Mellanby, E. (I92I). Spec. Rep. Ser. med. Res. Coun., Lond., no. 6I.

Mellanby, E. (I946). Brit. med. J. ii, 885 .

Michaud, L. (I940) (quoted by Michaud \& Elvehjem, 1943-4).

Michaud, L. \& Elvehjem, C. A. (1943-4). Nutr. Abstr. Rev. 13, 323.

Parsons, H. T., Foeste, A. \& Gilberg, N. (1945). f. Nutr. 29, 383.

Parsons, H. T., Williamson, A. \& Johnson, M. L. (1945). F. Nutr. 29, 373.

Phillips, P. H. \& Hart, E. B. (1939). Science, 90, 186.

Rose, W. C. \& Rice, E. E. (1939). Science, 90, 186.

Schaefer, A. E., McKibbin, J. M. \& Elvehjem, C. A. (1942). F. Nutr. 23, $49 x$.

von Mering, J. \& Minkowski, O. (1889). Arch. exp. Path. Pharmak. 26, 3.

Whitney, L. F. (1949). Feeding our Dogs. New York: Van Nostrand.

Williams, H. B., Riche, J. A. \& Lusk, G. (1912). F. biol. Chem. 12, 349.

Williams, R. J. (1942). Univ. Tex. Publ. 4237, 84 .

Williams, R. J., Beerstecher, E. Jr. \& Berry, L. T. (1950). Lancet, 258, 287.

Worden, A. N. (1955). Vet. Rec. 67, 173 .

\section{Some problems in the nutrition of the baby pig}

\author{
By D. B. Bellis, Unilever Ltd, Food Research Department, Sharnbrook, Beds
}

The young pig is almost unique because of its rapid rate of growth, which is comparable to that of the laboratory rat. At birth, the average piglet weighs $2 \frac{1}{2}-3 \mathrm{lb}$; ; this initial weight is doubled within a week and quadrupled in 3 weeks. At the traditional weaning age of 8 weeks, the young animal often weighs about $50 \mathrm{lb}$. The birth weight is increased about one-hundredfold at 7 months and mature animals may weigh about $600 \mathrm{lb}$. Such rapid growth makes exacting demands on nutrition and environment and inevitably presents many problems in the artificial rearing of baby pigs.

\section{Composition of colostrum and milk}

Perrin (1955) has shown that in the colostrum of the sow, like in that of other mammals, total solids and protein decrease rapidly and lactose increases during the first few hours after parturition (Table I). Comparison with the milk of other farm animals shows that sow's milk is high in energy and protein, and its ash content is among the highest of those of all mammals (Table 2). As regards the composition of the ash, the transition from colostrum to milk differs from that in other animals, since calcium and phosphorus are low in sow's colostrum and increase steadily 
Table I. Composition of sow's colostrum (Perrin, 1955)

$\begin{array}{ccccc}\begin{array}{c}\text { Time } \\ \text { after parturition }\end{array} & \begin{array}{c}\text { Total solids } \\ (\mathrm{h})\end{array} & \begin{array}{c}\text { Solids not fat } \\ (\%)\end{array} & \begin{array}{c}\text { Protein } \\ (\%)\end{array} & \begin{array}{c}\text { Lactose } \\ (\%)\end{array} \\ 0 & 27.6 & 21 \cdot 1 & 1 \% \cdot 0 & 3.1 \\ 3 & 25.4 & 19.5 & 15.5 & 3.3 \\ 6 & 24.2 & 17.3 & 13.7 & 3.3 \\ 12 & 19.2 & 13.6 & 9 \cdot 1 & 3.9 \\ 18 & 18.7 & 12.9 & 7 \cdot 4 & 4.5 \\ 24 & 18.2 & 11.9 & 6.8 & 4.6\end{array}$

Table 2. Composition of milk of various mammals

\begin{tabular}{|c|c|c|c|c|c|}
\hline Mammal & $\begin{array}{c}\text { Total solids } \\
(\%)\end{array}$ & $\begin{array}{l}\text { Fat } \\
(\%)\end{array}$ & $\begin{array}{l}\text { Sugar } \\
(\%)\end{array}$ & $\begin{array}{c}\text { Protein } \\
(\%)\end{array}$ & $\begin{array}{l}\text { Ash } \\
(\%)\end{array}$ \\
\hline Sow* & I $9 \cdot 9$ & $8 \cdot 3$ & 4.8 & $5 \cdot 6$ & $\mathrm{I} \cdot \mathrm{O}$ \\
\hline Mare & $9 \cdot 3$ & $\mathrm{I} \cdot \mathbf{2}$ & 6.9 & I.9 & 0.3 \\
\hline Cowt & $12 \cdot 7$ & $3 \cdot 8$ & 4.8 & $3 \cdot 4$ & 0.8 \\
\hline Goat $\uparrow$ & 17.7 & $7 \cdot 6$ & $5 \cdot 0$ & $4 \cdot 2$ & 0.8 \\
\hline Ewet & 20.5 & 8.6 & $4 \cdot 3$ & $6 \cdot 7$ & 1.0 \\
\hline
\end{tabular}

throughout lactation. The ascorbic-acid contents of the colostrum and milk are interesting; the values recorded (Braude, Coates, Henry, Kon, Rowland, Thompson \& Walker, 1947), $30 \mathrm{mg} / 100 \mathrm{ml}$. in colostrum and $13 \mathrm{mg} / \mathrm{100} \mathrm{ml}$. in milk, are considerably higher than those for most other mammals but the significance of this is not known.

\section{Artificial rearing}

The ease of rearing piglets artificially depends on the age at which weaning takes place. From 5 weeks of age onwards, few problems are presented; environment is not very important and temperatures of $60^{\circ} \mathrm{F}$. are adequate in normal quarters which should be free from damp and draughts. The young animal is able to digest to some extent cereal starches and animal and vegetable protein, and is not very susceptible to digestive upsets. We have shown that pigs weaned at 5 weeks make satisfactory growth on a diet of $15 \%$ fish meal, $6 \%$ soya-bean meal, $19 \%$ flaked maize, $20 \%$ sucrose and $40 \%$ oat flour with added vitamins $\mathrm{A}$ and $\mathrm{D}$ (diet $\mathrm{r}$ ). The diet contains no milk products and the cereal starches are slightly cooked during manufacture; sucrose is included to improve palatability. Progressively earlier weaning on to this diet leads to unsatisfactory growth and to an increasing number of deaths.

During the last 3 years, much work has been done in the U.S.A. and in this country on weaning piglets from 3 days to 3 weeks of age, and many reports describe suitable types of diet. We have found that a diet of $50 \%$ dried skim milk, $5 \%$ fat, $25 \%$ sucrose, $10 \%$ oat groats and $10 \%$ fish meal, supplemented with vitamin A (4500 i.u./lb.), vitamin $\mathrm{D}_{3}\left(900\right.$ i.u./lb.), vitamin $\mathrm{E}\left(4 \cdot 5\right.$ i.u./lb.), $\mathrm{FeSO}_{4} \cdot 7 \mathrm{H}_{2} \mathrm{O}(0 \cdot 45 \mathrm{~g} / \mathrm{lb}$.), 
$\mathrm{CuSO}_{4} \cdot 5 \mathrm{H}_{2} \mathrm{O}(0.0 \mathrm{r} \mathrm{g} / \mathrm{lb}$.) and aureomycin (chlortetracycline) $(25 \mathrm{mg} / \mathrm{lb}$ ) (diet 2) is successful in rearing piglets from 3 days of age. The diet is fed ad lib. as a gruel with water until the piglets are Io-14 days old, when they will consume the diet as a dry meal or pellet.

The growth of piglets on diet 2 is compared with that of normally suckled piglets in Fig. I, which shows that growth on diet 2 is subnormal from 3 days to $2 \frac{1}{2}$ weeks,

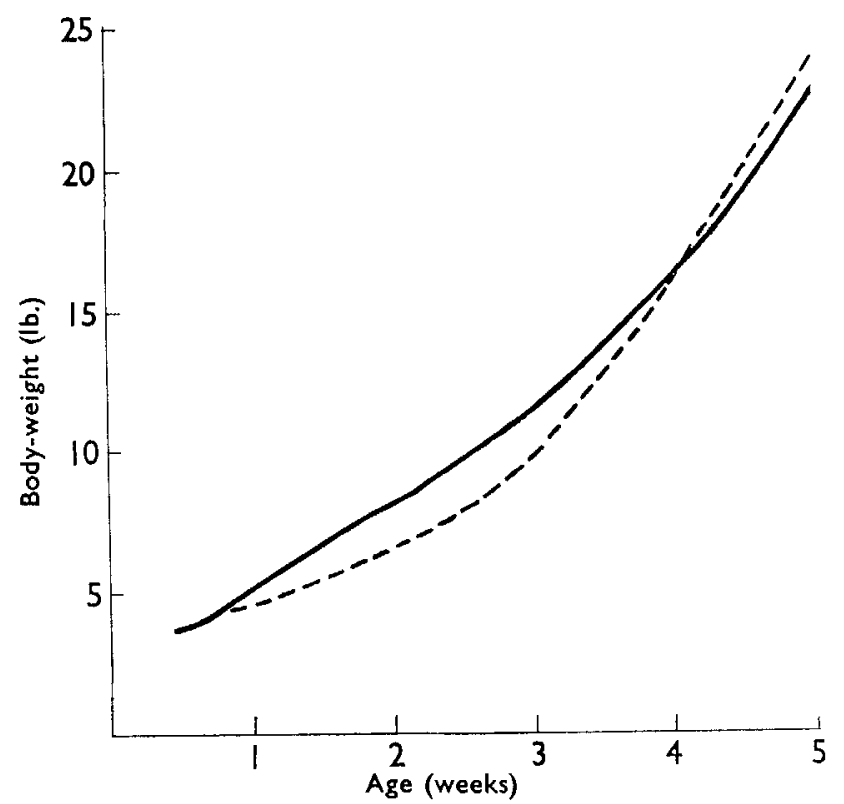

Fig. 1. Growth curves of piglets, suckled or artificially reared on diet 2, from 3 days of age.

and good from that stage onwards. The reasons for the poor growth during the first 2 weeks are not fully understood: they may be to some extent environmental or due to a marginal deficiency of a nutrient, but some evidence exists that at this stage the young animal is not able to digest the diet fully. Food conversion during the first 2 weeks is approximately $2 \cdot 3: \mathrm{I}$, but is considerably better $(\mathrm{I} \cdot 3: \mathrm{I})$ during the 3-5 week period. Decreasing the ratio, skim milk : fish-meal protein, with constant total protein leads to less efficient growth, but performance is almost constant at ratios above $2: \mathrm{I}$. These observations may be explained by a marginal deficiency of an amino-acid in fish meal, or by inferior digestion of the latter. Kvasnitskii \& Bakeeva ( 1943 ) have found that pepsin is present in the stomach of $\mathrm{I}$-day-old pigs but is not activated until the animal is 20-30 days old.

Assays (Catron, 1955) of the pancreas of pigs of 0-8 weeks of age have indicated that trypsin activity is adequate from birth; pancreatic amylase activity on the other hand is very low in the newborn piglet but rises rapidly to a maximum at 4-5 weeks. The 3 -day-old piglet is therefore not able to tolerate large quantities of starch in its diet and it has been found that glucose, sucrose and lactose are equally efficient and superior to pentoses or partly dextrinized starch for such pigs. Substitution of $10 \%$ of the sugar by oat groats leads to no loss of food efficiency or growth during 
the 3 days -2 weeks stage and is advantageous thereafter in controlling digestive upsets at $3-4$ weeks. The possible lack of enzymic activity may explain the unsuccessful use of diet I for pigs less than 5 weeks old.

Pigs weaned at 3 days are very sensitive to environmental factors and during the Ist week they should be housed in cages or boxes heated to a constant temperature of $70-75^{\circ} \mathrm{F}$. Beds should always be dry and feeding utensils cleaned and disinfected each day. Temperatures of $65^{\circ} \mathrm{F}$. are suitable from to days, when consumption of dry food begins, and although housing in a rabbit or guinea-pig cage is satisfactory, the provision of a small run is preferable.

When diet 2 is fed to pigs younger than $2-3$ days, mortality increases with progressively earlier weaning, and the survival of piglets that have received no colostrum is very unlikely; post-mortem examination reveals that the stomach, intestines and caecum contain the food as fed, with little evidence of digestion.

Becker, Ullrey, Terrill \& Notzold (1954) have found that piglets weaned at $24 \mathrm{~h}$ were unable to survive on a diet in which the carbohydrate consisted of sucrose, but grew successfully when the latter was replaced entirely by invert sugar; this indicates that sucrase is not active in the digestive system of pigs of less than 3 days of age.

Catron, Nelson, Ashton \& Maddock (1953) found 50\% survival of piglets fed from birth on a diet of dried skim milk and lard and antibiotics, when housed in completely new pig quarters, but subsequent trials in the same environment were not successful. Young \& Underdahl (195I, I953) and Young, Underdahl \& Hinz (1955) found that piglets removed from the sow by hysterectomy and kept in a sterile environment grew successfully on a diet of cow's milk supplemented by minerals and whole eggs. Such pigs did not receive colostrum, were never in contact with the sow or other pigs and were relatively free from disease. The piglets were not sterile but developed their initial microflora in the absence of other pigs; the primary source of their initial microflora was the pasteurized homogenized cow's milk.

We found that a high percentage of pigs, born normally but removed immediately to a clean environment, grew successfully on a diet similar to that of Young \& Underdahl, supplemented by antibiotic and sow blood serum. Transfer of these pigs to the experimental piggery even at 3 weeks invariably led to a number of deaths. Litter-mates of these pigs that received the same diet in the piggery from birth, died within a few days. After apparently satisfactory growth, death was generally sudden, and post-mortem examination indicated that it was due to a bacterial agency. The young pig is born without antibodies in its blood and they are obtained entirely from the colostrum, hence the provision of artificial colostrum is probably the most difficult problem that remains.

\section{REFERENCES}

Becker, D. E., Ullrey, D. E., Terrill, S. W. \& Notzold, R. A. (1954). Science, r20, 345.

Braude, R., Coates, M. E., Henry, K. M., Kon, S. K., Rowland, S. J., Thompson, S. Y. \& Walker, D. M. (1947). Brit. F. Nutr. I, 64 .

Catron, D. V. (1955). Feedstuffs, 28, no. I 8, p. 50. 
Catron, D. V., Nelson, L. F., Ashton, G. C. \& Maddock, H. M. (1953). F. Anim. Sci. 12, 62. Davies, W. L. (1939). The Chemistry of Milk, and ed. London: Chapman and Hall Ltd.

Kvasnitskil, A. V. \& Bakeeva, E. N. (1943). Vet. Bull. 13, 222.

Perrin, D. R. (1955). F. Dairy Res. 22, 103.

Young, G. A. Jr. \& Underdahl, N. R. (195I). Arch. Biochem. Biophys. 32, 449.

Young, G. A. \& Underdahl, N. R. (1953). Amer. F. vet. Res. 14, 57 I.

Young, G. A., Underdahl, N. R. \& Hinz, R. W. (1955). Amer. F. vet. Res. 16, 123. 